\title{
Video Retrieval Berdasarkan Teks dan Gambar
}

\author{
Rahmi Hidayati*1, Agus Harjoko ${ }^{2}$ \\ ${ }^{1}$ Program Studi S2/S3 Ilmu Komputer, FMIPA UGM, Yogyakarta \\ ${ }^{2}$ Jurusan Ilmu Komputer dan Elektronika, FMIPA UGM, Yogyakarta \\ e-mail: ${ }^{1}$ rahmihidayati86@gmail.com, ${ }^{2}$ aharjoko@ gmail.com
}

\begin{abstract}
Abstrak
Video retrieval digunakan untuk melakukan pencarian video berdasarkan query yang dimasukkan oleh user yaitu teks dan gambar. Sistem ini dapat meningkatkan kemampuan pencarian terhadap video dan diharapkan dapat mengurangi waktu temu-kembali video. Tujuan dari penelitian ini adalah merancang dan membuat sebuah aplikasi perangkat lunak video retrieval berdasarkan teks dan gambar yang ada dalam video. Proses indeks untuk teks adalah proses tokenizing, filtering (stopword), stemming. Hasil stemming disimpan dalam tabel indeks teks. Proses indeks untuk gambar adalah membuat histogram warna dan menghitung nilai rata-rata serta standar deviasi pada setiap warna dasar red, green dan blue $(R G B)$ dari setiap gambar. Hasil ekstraksi fitur disimpan pada tabel gambar.

Proses retrieval video menggunakan query yaitu teks, gambar atau keduanya. Untuk query teks sistem memproses query teks dengan melihat query teks pada tabel indeks teks. Jika query teks ada pada tabel indeks teks sistem akan menampilkan informasi video sesuai dengan teks query. Untuk query gambar sistem memproses query gambar dengan mencari nilai dari fitur ekstraksi yaitu means red, means green, means blue, standar deviasi red, standar deviasi green dan standar deviasi blue. Jika nilai hasil ekstraksi ke enam fitur query gambar ada pada tabel indeks gambar sistem akan menampilkan informasi video sesuai dengan gambar query. Untuk query teks dan query gambar, sistem akan menampilkan informasi video jika query teks dan query gambar memiliki keterkaitan yaitu query teks dan query gambar mempunyai judul film yang sama.
\end{abstract}

Kata kunci-video, indeks, retrieval, teks, gambar

\begin{abstract}
Retrieval video has been used to search a video based on the query entered by user which were text and image. This system could increase the searching ability on video browsing and expected to reduce the video's retrieval time. The research purposes were designing and creating a software application of retrieval video based on the text and image on the video. The index process for the text is tokenizing, filtering (stopword), stemming. The results of stemming to saved in the text index table. Index process for the image is to create an image color histogram and compute the mean and standard deviation at each primary color red, green and blue $(R G B)$ of each image. The results of feature extraction is stored in the image table

The process of video retrieval using the query text, images or both. To text query system to process the text query by looking at the text index tables. If there is a text query on the index table system will display information of the video according to the text query. To image query system to process the image query by finding the value of the feature extraction means red, green means, means blue, red standard deviation, standard deviation and standard deviation of blue green. If the value of the six features extracted query image on the index table image will display the video information system according to the query image. To query text and query images, the system will display the video information if the query text and query images have a relationship that is query text and query image has the same film title.
\end{abstract}

Keywords - video, index, retrieval, text, image

Received November $1^{\text {st }}$,2012; Revised December $1^{\text {st }}$, 2012; Accepted December $15^{\text {th }}$, 2012 


\section{PENDAHULUAN}

$\mathrm{V}$ ideo merupakan teknologi yang digunakan untuk menangkap, merekam, memproses dan menampilkan gambar sekaligus suara dalam waktu bersamaan. Suatu video dapat menyajikan informasi serta mengambarkan suatu proses kejadian Informasi dalam video dapat berupa gambar, cerita, suara dan teks. Video terdiri dari banyak gambar-gambar yang digabung biasanya disebut dengan frame.

Video retrieval adalah ilmu pencarian informasi pada video, pencarian untuk video itu sendiri, pencarian untuk metadata yang menjelaskan video atau mencari dalam database untuk teks, suara, gambar atau data. Penyimpanan informasi dan penemuan kembali informasi dapat dilakukan dengan mudah. Misalkan terdapat tempat penyimpanan video dan pengguna (user) memberikan suatu permintaan (request) atau query yang hasilnya adalah himpunan video yang mengandung informasi yang diperlukan yang diperoleh melalui query dari user. User bisa saja memperoleh video-video yang diperlukannya dengan membaca semua video dalam tempat penyimpanan, menyimpan video yang relevan dan membuang video yang tidak diinginkan, tetapi solusi ini tidak mudah karena user tidak memiliki waktu atau tidak ingin menghabiskan waktunya untuk membaca seluruh koleksi video.

Penerapan konsep video retrieval dapat dilakukan dalam sistem pencarian video yang telah dilakukan indeks. Sistem pencarian video bekerja dengan menerima masukan dari pengguna berupa query atau kata kunci. Pencarian dilakukan dengan menghitung tingkat kemiripan video yang ada pada indeks dengan query. Video retrieval digunakan untuk menentukan kembali (retrive) informasi-informasi yang relevan terhadap kebutuhan pengguna dari suatu kumpulan video indeks.

Dari permasalahan inilah memunculkan pemikiran bagaimana melakukan pencarian informasi pada video secara tepat dan relevan berdasarkan query yang dimasukkan oleh user yaitu teks, gambar dan keduanya. Pembuatan video retrieval dimulai dari proses ekstraksi teks dan gambar, proses indeks video untuk teks dan gambar dan pencarian video berdasarkan teks, gambar dan keduanya.

Penelitian ini merupakan pengembangan dari penelitian sebelumnya yang dilakukan oleh [1]. Penelitian tersebut mendeteksi dan mengenali teks terjemahan pada video menggunakan metode Grayscale Thinning dan Region Growing. Penelitian ini melakukan penambahan fitur video retrieval untuk pencarian informasi pada video berdasarkan teks dan gambar. Penelitian video retrieval yang telah dikembangkan sebelumnya dilakukan oleh [2] meneliti tentang Region-Based Video Content and Retrieval. Proses indeks yang digunakan adalah latent semantic indexing dan earth mover's distance. Proses retrieval menggunakan vector space model dan quantization. Neo, dkk [3] meneliti tentang video retrieval menggunakan High Level Features yaitu Exploiting Query Matching dan Confidence-based Weighting. Proses indeks yang digunakan adalah semantic indexing dan retrieval video menggunakan high level features. Christel dan Hauptman [4], meneliti video retrieval dengan High-level Semantic Features. Proses indeks dilakukan dengan mengekstrak fitur warna, tekstur dan anotasi. Proses retrieval video menggunakan high level semantic fitur.

\section{METODE PENELITIAN}

Masukan dari sistem video retrieval adalah video film dan query dari pengguna (user). Video film yang digunakan dalam sistem ini adalah video film dalam format AVI dan mempunyai teks terjemahan berbahasa Indonesia. Sistem ini terdiri dari dua proses yaitu proses indeks dan proses retrieval. Untuk proses indeks dilakukan terhadap teks dan gambar yang berasal dari video film. Untuk proses retrieval menggunakan query berupa teks, gambar atau keduanya. Keluaran yang diharapkan dari sistem ini adalah video yang dianggap sesuai oleh sistem berupa video berdasarkan relevansi dengan query yang diinputkan oleh pengguna.

IJCCS Vol. 7, No. 1, January 2013: $77-88$ 


\subsection{Proses Pembuatan Indeks}

Proses indeks dilakukan terhadap teks dan gambar. Sebelum melakukan proses indeks dilakukan proses ekstraksi video. Proses ekstraksi video membutuhkan masukkan dari user berupa video film yang akan diekstraksi. Hasil dari proses ekstraksi video adalah gambar berupa frame-frame video disimpan pada folder gambar. Setelah proses ekstraksi, dilakukan proses pengenalan karakter. Proses pengenalan karakter telah dilakukan pada penelitian oleh Septiarini [1].

Proses indeks teks mengggunakan hasil dari pengenalana karakter yang telah ada. Proses indeks teks menggunakan semua kata hasil pengenalan karakter. Proses indeks gambar dengan mengambil gambar hasil ekstraksi video berupa frame-frame video yang ada pada folder gambar dan proses indeks dilakukan pada semua gambar yang ada pada folder gambar. Tahapan-tahapan proses pembuatan indeks dibagi dua tahapan yaitu proses indeks untuk teks dan proses indeks untuk gambar. Diagram alur untuk pembuatan proses indeks dapat dilihat pada Gambar 1.

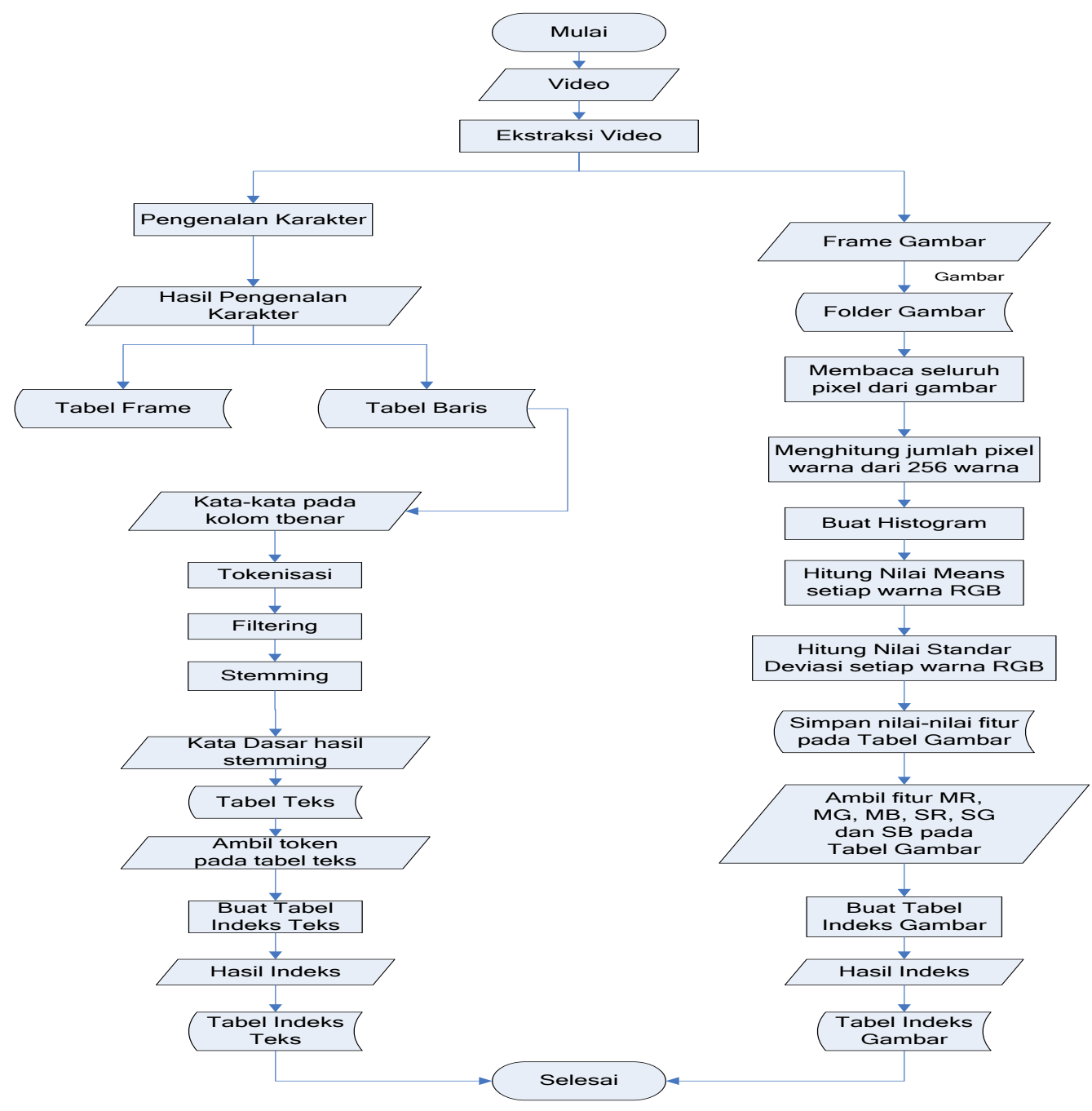

Gambar 1 Diagram Alur Proses Pembuatan Indeks

Proses indeks untuk teks dimulai dari proses proses tokenizing, yaitu unit melakukan pemotongan string input berdasarkan tiap kata yang menyusunnya. Hasil proses tokenizing adalah token. Proses filtering yaitu tahap mengambil kata-kata penting dari hasil token dan membuang kata-kata yang tidak penting dengan menggunakan algoritma stopword. Kata-kata tidak penting antara lain kata penghubung (sesudah, selesai, sebelum), kata bilangan (beberapa, 
banyak, sedikit), kata keterangan (sangat, hanya, lebih ), kata ganti (kami, mereka, kita) dan lain sebagainya. Proses stemming, yaitu proses untuk menghilangkan imbuhan, awalan, akhiran dan mengubah bentuk kata menjadi kata dasar. Proses stemming menggunakan Algoritma Porter untuk bahasa Indonesia [5]. Hasil proses stemming berupa kata dasar. Kemudian membuat tabel indeks teks menggunakan inverted list [6] dengan mengambil informasi kumpulan token yang ada pada tabel teks yaitu tabel sementara untuk menyimpan hasil stemming berupa token. Kemudian tiap-tiap token yang berbeda ditempatkan pada daftar inverted. Tabel indeks teks terdiri dari token yang memiliki informasi video, frekuensi token dan frame yang memuat token tersebut.

Proses indeks gambar dengan membaca seluruh pixel dari gambar tersebut, mengambil informasi warna dasarnya RGB dan menghitung kemunculan (pixel) untuk setiap skala warna dari 256 warna pada masing-masing warna dasar RGB. Kemudian membuat tabel histogram, dari data array histogram yang telah dihasilkan sebelumnya. Histogram dibuat untuk ke-3 warna dasar dengan array yang bersesuaian. Dari histogram yang dihasillkan dihitung nilai means (ratarata) dan standar deviasi untuk setiap nilai warna dasar RGB. Hasil perhitungan disimpan dalam tabel gambar. Setelah semua gambar diekstraksi, dibuat tabel indeks gambar untuk menyimpan nilai-nilai fitur ekstraksi yaitu means red (MR), means green (MG), means blue (MB), standar deviasi red (SR), standar deviasi green (SG) dan standar deviasi blue (SB) diperoleh dari tabel gambar. Setiap hasil ekstraksi berupa means red (MR), means green (MG), means blue (MB), standar deviasi red (SR), standar deviasi green (SG) dan standar deviasi blue (SB) ditempatkan pada daftar indeks berada dalam satu kolom yaitu kolom feature. Hasil fitur ekstraksi yang telah diindeks disimpan pada tabel indeks gambar. Tabel indeks gambar terdiri dari feature hasil ekstraksi yang memiliki informasi video dan frame yang memuat fitur-fitur tersebut

\subsection{Proses Retrieval Berdasarkan Teks}

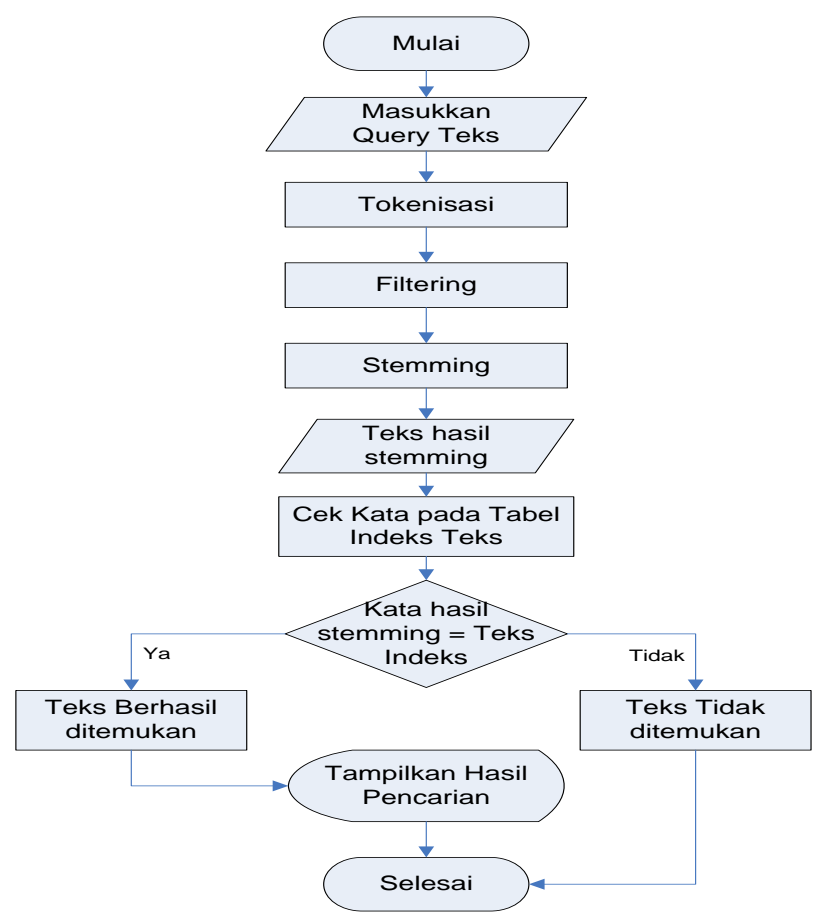

Gambar 2 Diagram Alur Proses Retrieval Berdasarkan Teks

Proses retrieval berdasarkan teks dilakukan dengan cara memasukkan query berupa teks, kemudian sistem akan memproses teks dengan melakukan tokenisasi, filtering (stopword) dan stemming. Hasil dari proses stemming berupa kata dasar. Kata hasil stemming dicek pada tabel indeks teks, jika kata tersebut ada pada tabel indeks teks maka sistem akan menampilkan

IJCCS Vol. 7, No. 1, January 2013: $77-88$ 
informasi video yang sesuai dengan query masukkan dari user. Dan jika kata tidak terdapat pada tabel indeks teks maka sistem akan memberikan pesan peringatan yaitu data yang dicari tidak ditemukan. Diagram alur untuk proses retrieval berdasarkan teks dapat dilihat pada Gambar 2.

\subsection{Proses Retrieval Berdasarkan Gambar}

Proses retrieval berdasarkan gambar dengan memasukkan query berupa gambar. Query gambar diproses dengan melakukan ekstraksi fitur, membuat histogram warna, mengambil informasi warna dasar (RGB), menghitung kemunculan (pixel) untuk setiap skala warna dari 256 warna pada masing-masing warna dasar (RGB), menghitung nilai rata-rata warna dan standar deviasi dari setiap warna RGB pada gambar query. Nilai ekstraksi fitur gambar query dibandingkan dengan nilai ekstraksi fitur pada gambar indeks.

Nilai ekstraksi yang digunakan adalah nilai means red (MR), means green (MG), means blue (MB), standar deviasi red (SR), standar deviasi green (SG) dan standar deviasi blue (SB). Jika semua nilai hasil ekstraksi ke enam fitur query gambar ada pada tabel indeks gambar maka sistem akan menampilkan informasi video sesuai dengan query masukkan dari user. Jika salah satu dari nilai fitur query gambar tidak terdapat pada tabel indeks gambar maka sistem akan memberikan pesan peringatan yaitu data yang dicari tidak ditemukan. Diagram alur untuk proses retrieval berdasarkan gambar dapat dilihat pada Gambar 3.

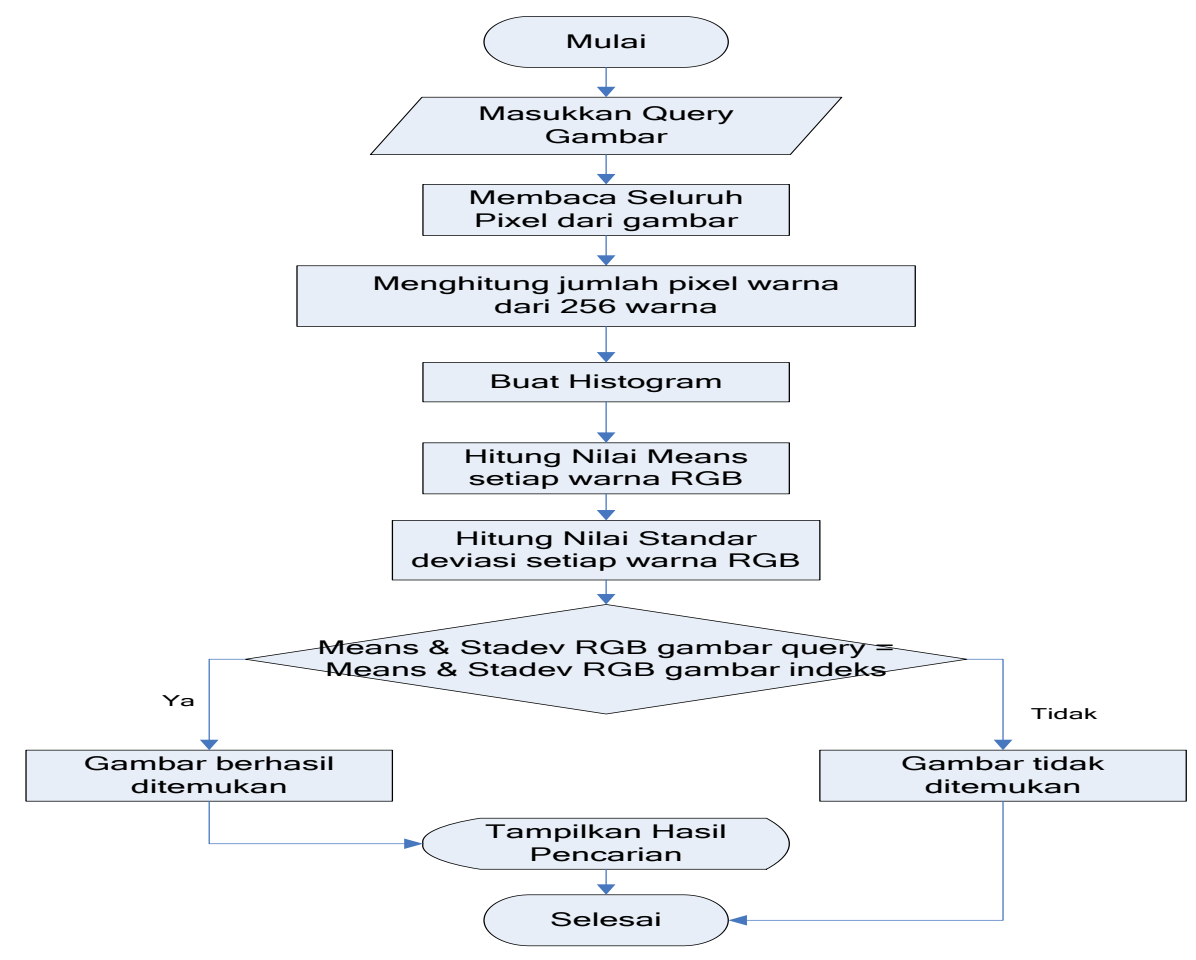

Gambar 3 Diagram Alur Proses Retrieval Berdasarkan Gambar

\subsection{Proses Retrieval Berdasarkan Teks dan Gambar}

Proses retrieval berdasarkan teks dan gambar dilakukan dengan cara memasukkan query berupa teks dan gambar secara bersamaan. Setelah kedua query dimasukkan sistem akan melakukan proses terhadap query teks dan query gambar. Query teks diproses dengan melakukan tokenisasi, filtering (stopword) dan stemming. Hasil dari proses stemming berupa kata dasar. Kata hasil stemming dicek pada tabel indeks teks, jika kata tersebut ada pada tabel indeks teks maka sistem akan menampilkan informasi video yang sesuai dengan query masukkan dari user. Dan jika kata tidak terdapat pada tabel indeks teks maka sistem akan memberikan pesan peringatan yaitu data yang dicari tidak ditemukan. 
Query gambar diproses dengan melakukan ekstraksi fitur, membuat histogram warna, mengambil informasi warna dasar (RGB), menghitung kemunculan (pixel) untuk setiap skala warna dari 256 warna pada masing-masing warna dasar (RGB), menghitung nilai rata-rata warna dan standar deviasi dari setiap warna RGB pada gambar query. Nilai ekstraksi fitur gambar query dibandingkan dengan nilai ekstraksi fitur pada gambar indeks. Nilai ekstraksi yang digunakan adalah nilai means red (MR), means green (MG), means blue (MB), standar deviasi red (SR), standar deviasi green (SG) dan standar deviasi blue (SB). Jika semua nilai hasil ekstraksi ke enam fitur query gambar ada pada tabel indeks gambar maka sistem akan menampilkan informasi video sesuai dengan query masukkan dari user. Jika salah satu dari nilai fitur query gambar tidak terdapat pada tabel indeks gambar maka sistem akan memberikan pesan peringatan yaitu data yang dicari tidak ditemukan. Setelah kata hasil dari stemming query teks ditemukan dan nilai fitur hasil ekstraksi gambar ditemukan. Pencarian untuk dua query harus memiliki keterkaitan antara query teks dan query gambar yaitu dengan melihat judul film yang dimiliki oleh query tersebut. Jika judul film query teks sama dengan query gambar maka sistem akan menampilkan informasi video sesuai query keduanya. Jika judul film query teks dan query gambar tidak sama maka sistem akan memberikan pesan peringatan yaitu data yang dicari tidak ditemukan. Diagram alur untuk proses retrieval berdasarkan teks dan gambar dapat dilihat pada Gambar 4.

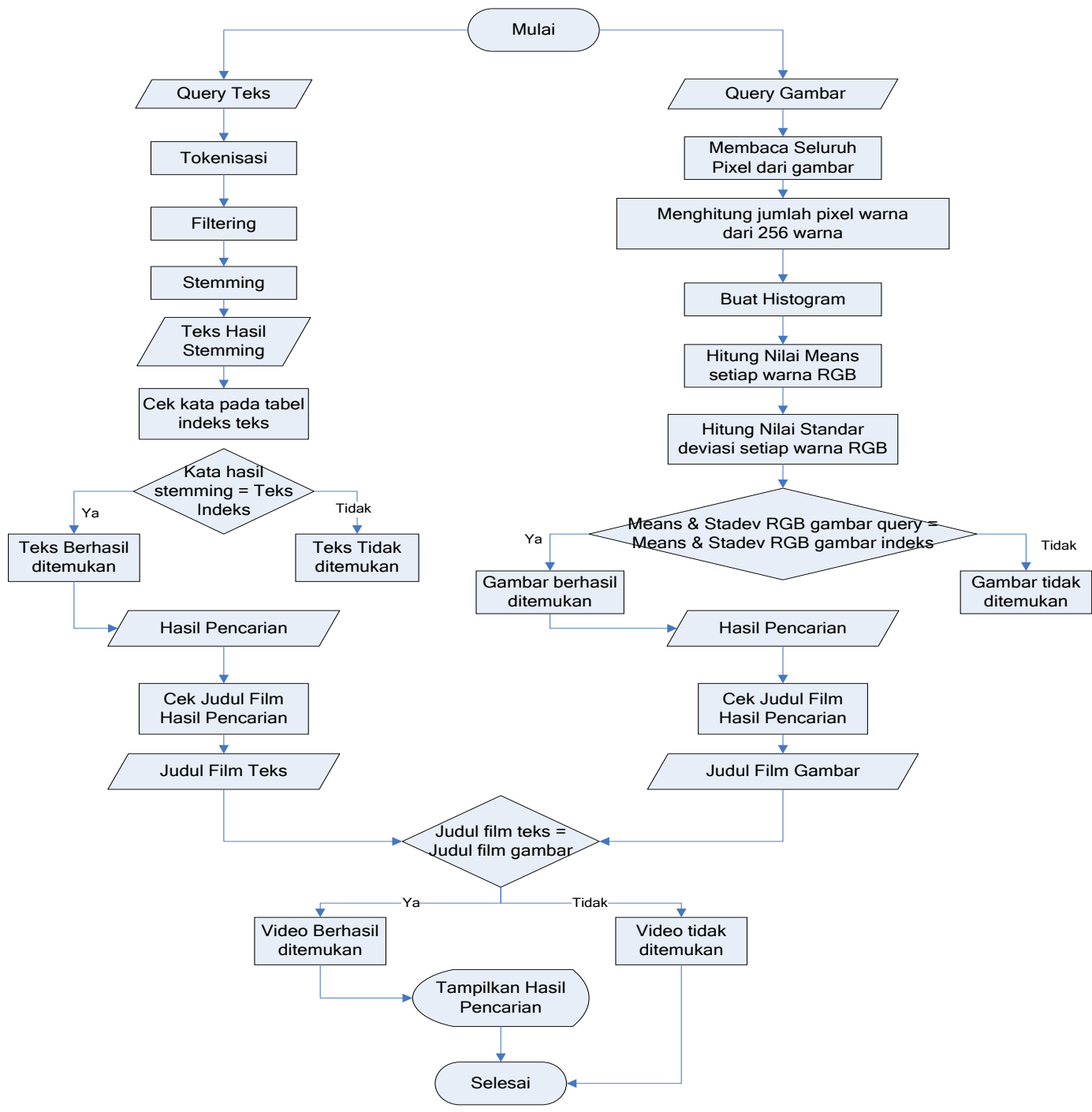

Gambar 4 Diagram Alur Proses Retrieval Berdasarkan Teks dan Gambar

IJCCS Vol. 7, No. 1, January 2013: $77-88$ 


\section{HASIL DAN PEMBAHASAN}

Proses indeks video terbagi atas dua bagian yaitu proses indeks untuk teks dan proses indeks untuk gambar. Pada proses indeks untuk teks, sistem melakukan proses indeks terhadap semua teks terjemahan pada video dari hasil pengenalan karakter. Hasil dari proses indeks adalah token, filmfrekuensi dan frame-frame yang memuat token hasil indeks. Tampilan indeks untuk teks dapat dilihat pada Gambar 5.

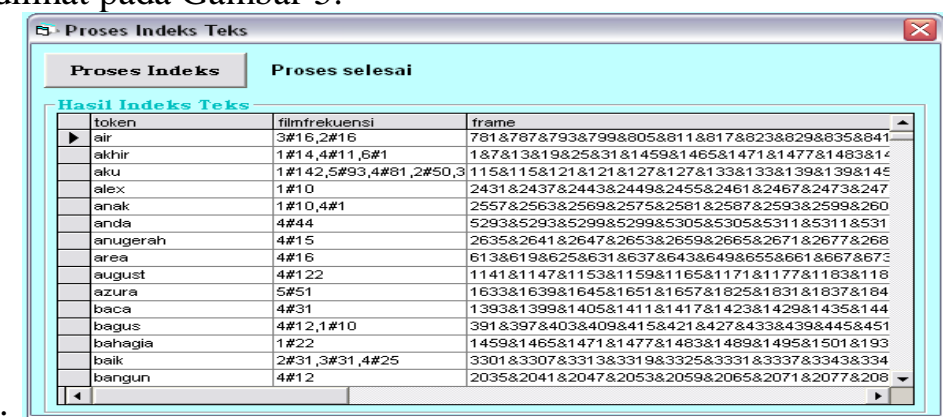

Gambar 5 Tampilan Indeks Teks

Proses indeks pada gambar, sistem melakukan proses indeks terhadap semua nilai fitur ekstraksi dari setiap gambar yang telah diekstraksi. Hasil dari indeks gambar berupa Id, feature, film dan frame-frame yang memuat feature indeks. Tampilan indeks untuk gambar dapat dilihat pada Gambar 6.

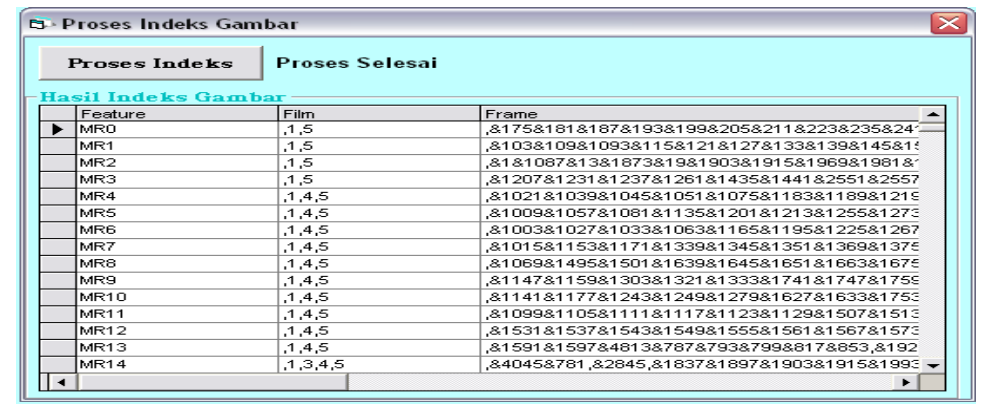

Gambar 6 Tampilan Indeks Gambar

Proses pencarian video menggunakan query teks, gambar atau keduanya. Proses pencarian untuk teks, user memasukkan query teks yang akan dicari. Kemudian pilih option OR dan klik tombol cari. Hasil dari pencarian teks adalah informasi video yaitu judul film dan frame-frame yang sesuai dengan query teks masukkan dari user. Tampilan pencarian berdasarkan teks dapat dilihat pada Gambar 7.

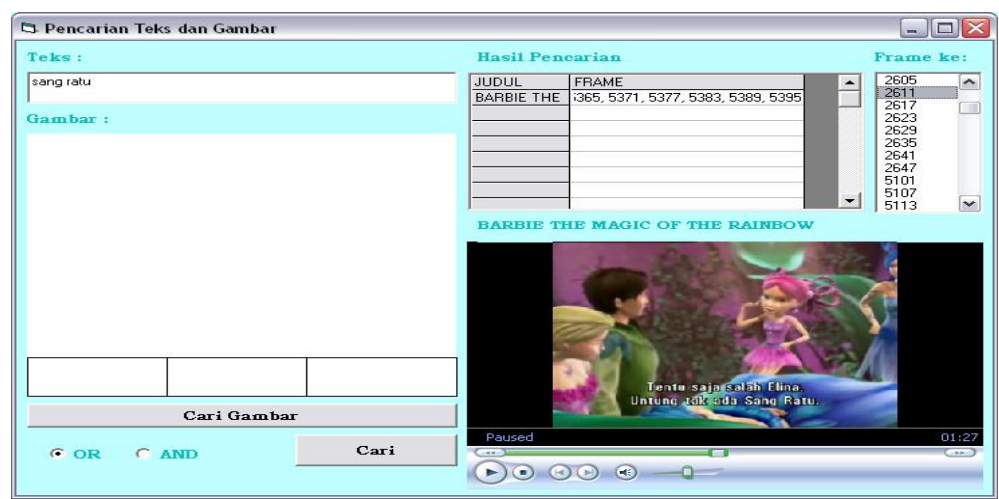

Gambar 7 Tampilan Pencarian Berdasarkan Teks 
Proses pencarian untuk gambar, user memasukkan query gambar yang akan dicari. Kemudian pilih option OR dan klik tombol cari. Hasil dari pencarian gambar adalah informasi video yaitu judul film dan frame- frame yang sesuai dengan query gambar masukkan dari user. Tampilan pencarian berdasarkan gambar dapat dilihat pada Gambar 8.

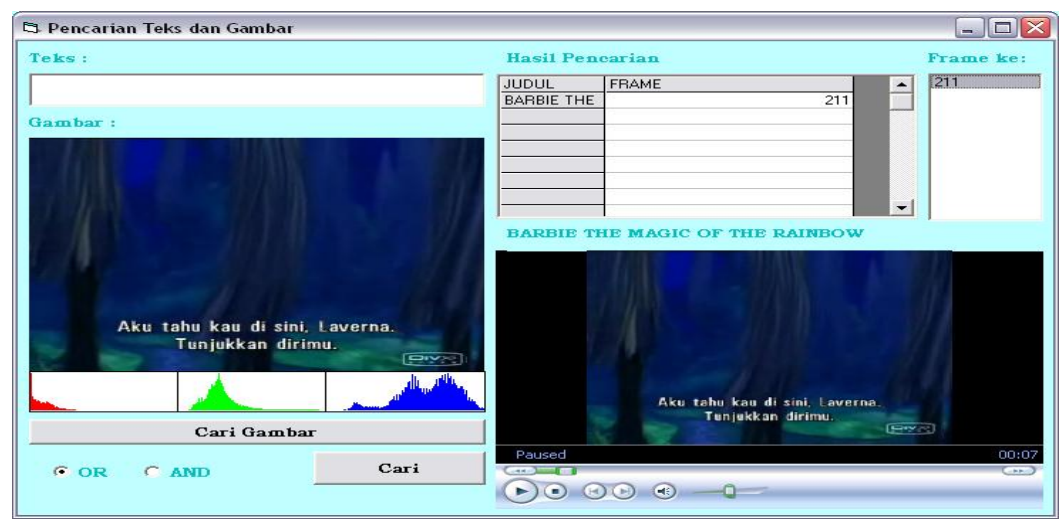

Gambar 8 Tampilan Pencarian Berdasarkan Gambar

Proses pencarian untuk teks atau gambar dengan operator OR, user bisa memasukkan query teks atau gambar yang akan dicari. Setelah memasukkan query teks atau query gambar atau keduanya, pilih option OR dan klik tombol cari. Hasil dari pencarian teks atau gambar dengan operator OR, adalah informasi video yaitu judul film dan frame yang sesuai dengan query teks dan gambar yang diinputkan oleh user. Tampilan pencarian untuk teks atau gambar operator OR dapat dilihat pada Gambar 9.

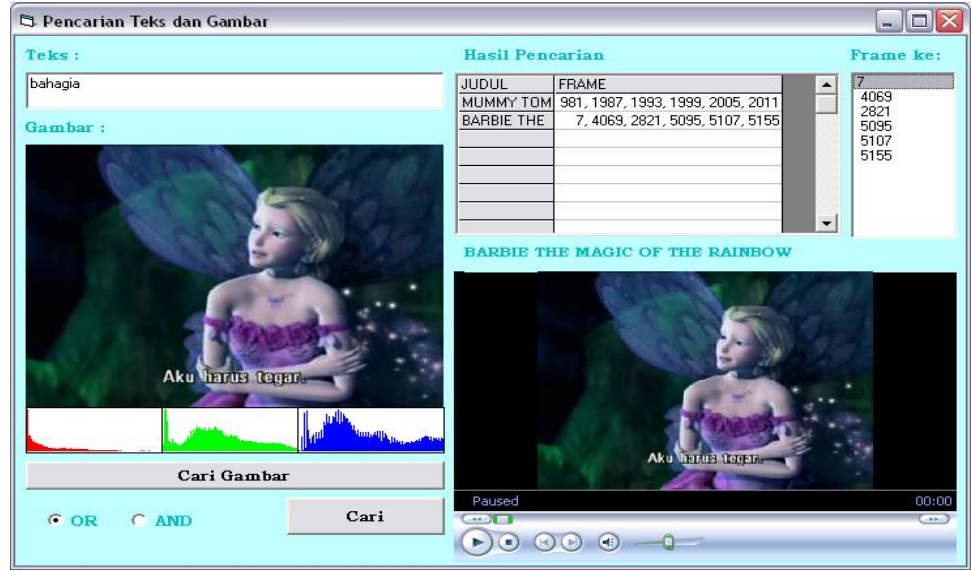

Gambar 9 Tampilan Pencarian Berdasarkan Teks atau Gambar Operator OR

Proses pencarian untuk teks dan gambar dengan operator AND, user harus memasukkan query teks dan query gambar yang akan dicari. Setelah memasukkan query teks dan query gambar, pilih option AND dan klik tombol cari. Hasil dari pencarian teks dan gambar dengan operator AND adalah informasi video yaitu judul film dan frame yang sesuai dengan query teks dan gambar yang diinputkan oleh user. Pencarian menggunakan operator AND antara query teks dan query gambar harus memiliki keterkaitan. Keterkaitan yang dimiliki adalah judul film query teks dan query gambar harus sama. Jika judul film tidak sama maka sistem tidak memberikan informasi video karena video yang dicari tidak ditemukan. Tampilan pencarian untuk teks dan gambar operator AND dapat dilihat pada Gambar 10. 


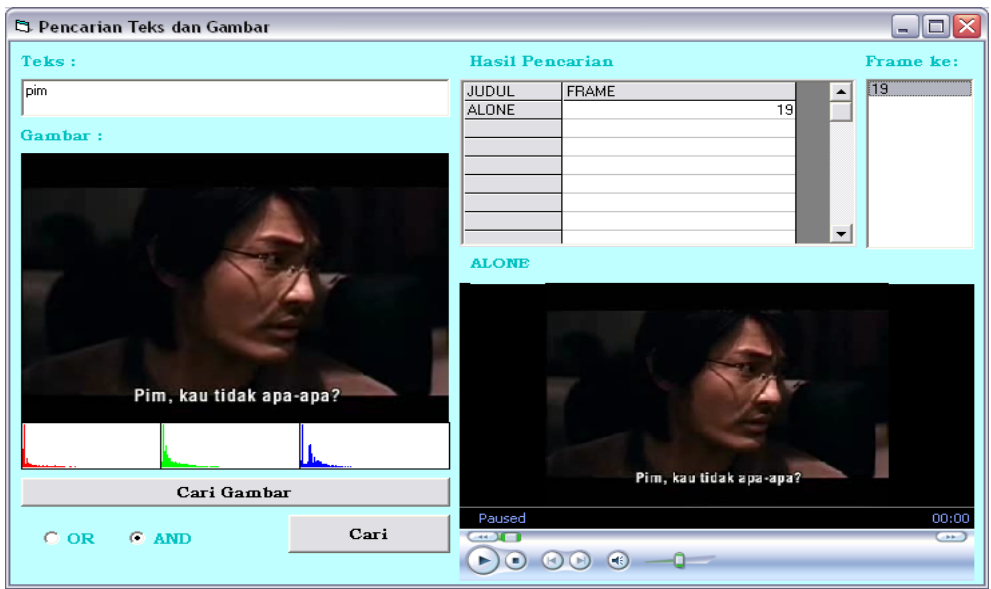

Gambar 10 Tampilan Proses Pencarian Teks dan Gambar Operator AND

Pengujian untuk teks menggunakan perhitungan dengan precision dan recall. Sistem akan diujicoba terhadap 35 teks yang diambil dari teks yang ada pada video film. Pengujian akan difokuskan pada relevansi dari hasil perhitungan precision dan recall. Precision dapat diartikan sebagai kemiripan atau kecocokan antara permintaan informasi dengan jawaban terhadap permintaan itu. Jika seseorang mencari informasi di sebuah sistem dan sistem menawarkan beberapa video, maka kemiripan ini sebenarnya juga adalah relevansi. Artinya, seberapa mirip atau cocok video tersebut untuk keperluan pencari informasi, bergantung pada seberapa relevan video tersebut bagi pencari. Recall adalah proporsi jumlah video yang dapat ditemukan-kembali oleh sebuah proses pencarian di sistem IR. Rumus recall: Jumlah teks relevan yang ditemukan / Jumlah semua teks relevan di dalam database. Lalu, precision adalah proporsi jumlah teks yang ditemukan dan dianggap relevan untuk kebutuhan pencari informasi. Rumus precision: Jumlah teks relevan yang ditemukan/Jumlah semua teks yang ditemukan. Hasil pengujian menggunakan precision dan recall menggunakan 35 teks uji adalah semakin tinggi nilai precision maka nilai recall semakin turun. Pengujian precision menghasilkan nilai sebesar $100 \%$ dan recall menghasilkan nilai sama atau lebih rendah dari precision. Hasil pengujian dengan query teks dapat dilihat pada Tabel 1.

Pengujian untuk gambar dilakukan pada 40 gambar yang berbeda dari empat judul film yaitu barbie, alone, august rush dan mumi serta lima gambar bukan dari data film yang ada pada sistem. Pencarian gambar berhasil ditemukan jika semua nilai hasil ekstraksi fitur gambar query dengan hasil ekstraksi pada indeks gambar memiliki nilai yang sama. Pencarian gambar dapat menghasilkan lebih dari satu frame, karena frame-frame yang dihasilkan memiliki hasil ektraksi fitur yang sama persis dengan hasil gambar query sehingga semua nilai hasil ekstraksi fitur yang sama dengan gambar query akan ditampilkan walaupun tidak berada dalam video yang sama. Ada dua gambar pada proses pencarian gambar yang tidak berhasil ditemukan karena hasil ekstraksi tidak ada dalam indeks gambar dan sistem tidak bisa mengambil hasil ekstraksi fitur akan muncul pesan kesalahan 'Out of string space'. Dan dua gambar lainnya tidak bisa ditemukan karena, query gambar tidak ada pada indeks gambar tetapi pada proses pencarian, gambar lain muncul sebagai hasil. Dari 40 gambar yang diuji 36 gambar berhasil ditemukan dan 4 gambar tidak berhasil ditemukan. Perhitungan persentase gambar berhasil ditemukan dari 40 gambar uji adalah $36 / 40 \times 100=90 \%$. Dan persentase gambar gagal ditemukan adalah $4 / 40 \times$ $100=10 \%$. Hasil pengujian dengan query gambar pencarian gambar dapat dilihat pada Tabel 2. 
Tabel 1 Hasil Pengujian dengan Query Teks

\begin{tabular}{|c|c|c|c|c|c|}
\hline No. & Teks & $\begin{array}{l}\text { Jumlah semua kata } \\
\text { relevan pada database }\end{array}$ & $\begin{array}{l}\text { Jumlah kata } \\
\text { relevan yang } \\
\text { ditemukan }\end{array}$ & Recall & Precision \\
\hline 1. & Air & 32 Frame & 32 Frame & $100 \%$ & $100 \%$ \\
\hline 2. & Akhir & 25 Frame & 11 Frame & $44 \%$ & $100 \%$ \\
\hline 3. & $\mathrm{Aku}$ & 415 Frame & 142 Frame & $34 \%$ & $100 \%$ \\
\hline 4. & Bagus & 22 Frame & 12 Frame & $54 \%$ & $100 \%$ \\
\hline 5. & Bahagia & 22 Frame & 22 Frame & $100 \%$ & $100 \%$ \\
\hline 6. & Belajar & 13 Frame & 13 Frame & $100 \%$ & $100 \%$ \\
\hline 7. & Biar & 44 Frame & 44 Frame & $100 \%$ & $100 \%$ \\
\hline 8. & Bicara & 52 Frame & 52 Frame & $100 \%$ & $100 \%$ \\
\hline 9. & Bisa & 233 Frame & 61 Frame & $26 \%$ & $100 \%$ \\
\hline 10. & Butuh & 27 Frame & 16 Frame & $59 \%$ & $100 \%$ \\
\hline 11. & Darah & 48 Frame & 48 Frame & $100 \%$ & $100 \%$ \\
\hline 12. & Egois & 26 Frame & 26 Frame & $100 \%$ & $100 \%$ \\
\hline 13. & Hancur & 18 Frame & 12 Frame & $66 \%$ & $100 \%$ \\
\hline 14. & Hasrat & 19 Frame & 19 Frame & $10 \%$ & $100 \%$ \\
\hline 15. & Ide & 8 Frame & 8 Frame & $100 \%$ & $100 \%$ \\
\hline 16. & Ikan & 8 Frame & 8 Frame & $100 \%$ & $100 \%$ \\
\hline 17. & Inspirasi & 13 Frame & 13 Frame & $100 \%$ & $100 \%$ \\
\hline 18. & Istirahat & 44 Frame & 44 Frame & $100 \%$ & $100 \%$ \\
\hline 19. & Jalan & 64 Frame & 56 Frame & $87 \%$ & $100 \%$ \\
\hline 20. & Janji & 12 Frame & 12 Frame & $100 \%$ & $100 \%$ \\
\hline 21. & Jujur & 13 Frame & 13 Frame & $100 \%$ & $100 \%$ \\
\hline 22. & Kabar & 25 Frame & 15 Frame & $60 \%$ & $100 \%$ \\
\hline 23. & Karakter & 16 Frame & 16 Frame & $100 \%$ & $100 \%$ \\
\hline 24. & Karya & 33 Frame & 20 Frame & $60 \%$ & $100 \%$ \\
\hline 25. & Kasih & 21 Frame & 21 Frame & $100 \%$ & $100 \%$ \\
\hline 26. & Otak & 48 Frame & 48 Frame & $100 \%$ & $100 \%$ \\
\hline 27. & Pindah & 30 Frame & 30 Frame & $100 \%$ & $100 \%$ \\
\hline 28. & Pisah & 20 Frame & 20 Frame & $100 \%$ & $100 \%$ \\
\hline 29. & Sang & 22 Frame & 16 Frame & $72 \%$ & $100 \%$ \\
\hline 30. & Tadi & 30 Frame & 22 Frame & $73 \%$ & $100 \%$ \\
\hline 31. & Tegang & 23 Frame & 23 Frame & $100 \%$ & $100 \%$ \\
\hline 32. & Terima & 36 Frame & 15 frame & $41 \%$ & $100 \%$ \\
\hline 33. & Tulis & 25 Frame & 15 frame & $60 \%$ & $100 \%$ \\
\hline 34. & Usaha & 14 Frame & 14 Frame & $100 \%$ & $100 \%$ \\
\hline 35. & Yakin & 32 Frame & 19 Frame & $59 \%$ & $100 \%$ \\
\hline
\end{tabular}

Tabel 2 Hasil Pengujian dengan Query Gambar

\begin{tabular}{|c|l|l|l|c|c|}
\hline No & $\begin{array}{c}\text { Judul } \\
\text { Film }\end{array}$ & $\begin{array}{c}\text { Frame yang } \\
\text { dicari }\end{array}$ & \multicolumn{1}{|c|}{ Hasil Pencarian } & $\begin{array}{c}\text { Pencarian } \\
\text { Berhasil }\end{array}$ & $\begin{array}{c}\text { Pencarian } \\
\text { Gagal }\end{array}$ \\
\hline 1. & Barbie & Frame-7 & Barbie Frame-7 & $\checkmark$ & - \\
\hline 2. & Barbie & Frame-91 & Barbie Frame-91 & $\checkmark$ & - \\
\hline 3. & Barbie & Frame-55 & Barbie Frame-55, Barbie Frame-667 & $\checkmark$ & - \\
\hline 4. & Barbie & Frame-121 & Barbie Frame-121, Barbie Frame-181 & $\checkmark$ & - \\
\hline 5. & Barbie & Frame-235 & Barbie Frame-235 & $\checkmark$ & - \\
\hline 6. & Barbie & Frame-523 & Barbie Frame-523 & $\checkmark$ & - \\
\hline 7. & Barbie & Frame-829 & Barbie Frame-829 & $\checkmark$ & - \\
\hline 8. & Barbie & Frame-1033 & Barbie Frame-1033 & $\checkmark$ & - \\
\hline 9. & Alone & Frame-7 & Alone Frame-7 & $\checkmark$ & - \\
\hline 10. & Alone & Frame-781 & Alone Frame-781 & $\checkmark$ & - \\
\hline 11. & Alone & Frame-1285 & Alone Frame-1285 & $\checkmark$ & - \\
\hline 12. & Alone & Frame-992 & Alone Frame-991 & $\checkmark$ & - \\
\hline 13. & Alone & Frame-1639 & Alone Frame-1639, Alone Frame-517 & - \\
\hline 14. & Alone & Frame-2011 & Alone Frame-2011, Alone Frame-1999 & $\checkmark$ & - \\
\hline 15. & Alone & Frame-1057 & Alone Frame-1057 & $\checkmark$ & - \\
\hline 16. & Alone & Frame-3781 & Alone Frame-3781, Alone Frame-3787 & $\checkmark$ & - \\
\hline 17. & Alone & Frame-901 & Alone Frame-901 & $\checkmark$ & - \\
\hline
\end{tabular}

IJCCS Vol. 7, No. 1, January 2013 : $77-88$ 


\begin{tabular}{|c|c|c|c|c|c|}
\hline 18. & Alone & Frame-3871 & Alone Frame-3871 & $\checkmark$ & - \\
\hline 19. & $\begin{array}{l}\text { August } \\
\text { Rush }\end{array}$ & Frame-7 & $\begin{array}{l}\text { August Rust Frame-1, August Rust } \\
\text { Frame-7, August Rust Frame-73, August } \\
\text { Rust Frame-91, August Rust Frame-97, } \\
\text { August Rust Frame-115 }\end{array}$ & $\checkmark$ & - \\
\hline 20. & $\begin{array}{l}\text { August } \\
\text { Rush }\end{array}$ & Frame-145 & $\begin{array}{l}\text { August Rush Frame-145, August Rush } \\
\text { Frame-163, August Rush Frame-175 }\end{array}$ & $\checkmark$ & - \\
\hline 21. & $\begin{array}{l}\text { August } \\
\text { Rush }\end{array}$ & Frame-751 & August Rush Frame-751 & $\checkmark$ & - \\
\hline 22. & $\begin{array}{l}\text { August } \\
\text { Rush }\end{array}$ & Frame-1063 & August Rush Frame-1063 & $\checkmark$ & - \\
\hline 23. & $\begin{array}{l}\text { August } \\
\text { Rush }\end{array}$ & Frame-325 & $\begin{array}{l}\text { August Rush Frame-325, August Rush } \\
\text { Frame-331 }\end{array}$ & $\checkmark$ & - \\
\hline 24. & $\begin{array}{l}\text { August } \\
\text { Rush }\end{array}$ & Frame-439 & $\begin{array}{l}\text { August Rush Frame- 439, } \\
\text { August Rush Frame-61 }\end{array}$ & $\checkmark$ & - \\
\hline 25. & $\begin{array}{l}\text { August } \\
\text { Rush }\end{array}$ & Frame-793 & $\begin{array}{l}\text { August Rush Frame- 793, } \\
\text { August Rush Frame- 745, } \\
\text { August Rush Frame- 757, } \\
\text { August Rush Frame- } 775\end{array}$ & $\checkmark$ & - \\
\hline 26. & $\begin{array}{l}\text { August } \\
\text { Rush }\end{array}$ & Frame- 823 & August Rush Frame- 823 & $\checkmark$ & - \\
\hline 27. & $\begin{array}{l}\text { August } \\
\text { Rush }\end{array}$ & Frame-1165 & $\begin{array}{l}\text { August Rush Frame- 1165, } \\
\text { August Rush Frame- 1183 }\end{array}$ & $\checkmark$ & - \\
\hline 28. & Mumi & Frame-13 & Mumi Frame-13 & $\checkmark$ & - \\
\hline 29. & Mumi & Frame-121 & Tidak bisa ditemukan & - & $\checkmark$ \\
\hline 30. & Mumi & Frame-361 & Mumi Frame-361 & $\checkmark$ & - \\
\hline 31. & Mumi & Frame-457 & $\begin{array}{l}\text { Mumi Frame-457, Mumi Frame-433, } \\
\text { Mumi Frame-445, } \\
\text { Mumi Frame-451, Mumi Frame-457, } \\
\text { Barbie Frame-3379 }\end{array}$ & $\checkmark$ & - \\
\hline 32. & Mumi & Frame- 829 & Mumi frame-829 & $\checkmark$ & - \\
\hline 33. & Mumi & Frame-3991 & Mumi Frame-3991 & $\checkmark$ & - \\
\hline 34. & Mumi & Frame-2479 & Tidak bisa ditemukan & - & $\checkmark$ \\
\hline 35. & Mumi & Frame-1321 & Mumi Frame-1321 & $\checkmark$ & - \\
\hline 36. & - & Bunga 1 & Tidak bisa ditemukan & $\checkmark$ & - \\
\hline 37. & - & Bunga 2 & Tidak bisa ditemukan & $\checkmark$ & - \\
\hline 38. & - & Bunga 3 & Tidak bisa ditemukan & $\checkmark$ & - \\
\hline 39. & - & Bunga 4 & $\begin{array}{l}\text { Mumi Frame 5329, } \\
\text { Barbie Frame } 4195\end{array}$ & - & $\checkmark$ \\
\hline 40. & - & Bunga 5 & Mumi Frame 361 & - & $\checkmark$ \\
\hline
\end{tabular}

\section{KESIMPULAN}

Dari uraian keseluruhan yang telah dikemukakan dari proses perancangan sampai pada implementasi sistem dari hasil penelitian yang dilakukan dapat ditarik kesimpulan sebagai berikut:

1. Pengujian untuk pencarian teks menggunakan perhitungan dengan precision dan recall. Hasil pengujian menggunakan precision menggunakan 35 teks uji menghasilkan nilai sebesar $100 \%$ dan recall menghasilkan nilai sama atau lebih rendah dari precision.

2. Pengujian untuk pencarian gambar menggunakan 40 gambar uji menghasilkan persentase sebesar $90 \%$ gambar berhasil ditemukan.

3. Proses pencarian gambar akan menghasilkan gambar yang memiliki nilai fitur ekstraksi yang sama antara gambar query dengan gambar yang ada pada tabel indeks gambar.

4. Pencarian gambar tidak ditemukan jika gambar yang dicari nilai fiturnya tidak ada dalam indeks gambar. 
5. Pencarian video menggunakan operator OR dapat melakukan pencarian teks, gambar atau keduanya. Hasil pencarian dengan OR akan menghasilkan informasi video yang memuat teks atau gambar sesuai dengan query yang dimasukkan.

6. Pencarian video menggunakan operator AND melakukan pencarian query teks dan query gambar yang saling memiliki keterkaitan. Jika query teks terdapat dalam query gambar ataupun sebaliknya maka sistem akan menampilkan informasi video yang dicari. Jika query teks tidak terdapat dalam query gambar ataupun sebaliknya maka sistem akan memberi pesan peringatan bahwa pencarian tersebut tidak ditemukan.

\section{SARAN}

Berdasarkan pengujian yang telah dilakukan pada aplikasi video retrieval yang dibuat, masih terdapat kekurangan dan kelemahan sehingga peneliti memberikan saran untuk pengembangan sistem kedepan atau untuk peneliti yang akan mengembangkan sistem berikutnya :

1. Penambahan jumlah film, sehingga mendapatkan banyak variasi teks untuk proses indeks teks.

2. Pencarian gambar berdasarkan ciri warna belum cukup untuk mengidentifikasi sebuah gambar lebih detail, hal ini dikarenakan bila lebih dari satu gambar memiliki warna yang sama maka akan terdapat dua gambar atau lebih dengan ciri yang sama. Untuk itu pencarian gambar berdasarkan warna perlu digabung dengan ciri bentuk ataupun yang lainnya.

\section{UCAPAN TERIMA KASIH}

Puji syukur Alhamdulillah kami panjatkan kepada Allah SWT. yang telah memberikan semua nikmatnya sehingga peneliti dapat menyelesaikan penelitian ini, Sholawat serta salam selalu tercurahkan kepada baginda Rasulullah SAW. Yang telah membawa dunia penuh dengan ilmu pengetahuan, terimakasih tidak lupa kami sampaikan kepada kedua orangtua tercinta, seluruh staff dan pengajar pasca sarjana jurusan Ilmu komputer Fakultas MIPA Universitas Gadjah Mada Yogyakarta dan semua yang telah membantu penyelesaian penelitian ini.

\section{DAFTAR PUSTAKA}

[1] Septiarini, A., 2009, Pendeteksian dan Pengenalan Teks terjemahan Pada Video Menggunakan Metode Grayscale Thinning dan Region Growing, Tesis, Program Pasca Sarjana Ilmu Komputer, Universitas Gadjah Mada, Yogyakarta.

[2] Souvannavong, F., Merialdo, B., dan Huet, B., 2006, Region-Based Video Content Indexing and Retrieval, France Pattent No:06904

[3] Neo, S., Zhoa, J., Kan M., dan Chua, T., 2006, Video Retrieval using High Level Features: Exploiting Query Matching and Confidence-based Weighting, Department of Computer Science, School of Computing, National University of Singapore, Singapore.

[4] Christel, M., and Hauptmann, A., 2005, The Use and Utility of High-Level Semantic Features in Video Retrieval, School of Computer Science, Carnegie Mellon University, Pittsburgh, PA, USA.

[5] Agusta, Ledy., 2009, Perbandingan Algoritma Stemming Porter dengan Algoritma Nazief \& Adrian untuk Stemming Dokumen Teks Bahasa Indonesia, Konferensi Nasional Sistem dan Informatika, Bali.

[6] Mooney, J. R., 2006, Machine Learning Text Categorization, University of Texas, Austin.

IJCCS Vol. 7, No. 1, January 2013 : $77-88$ 